\title{
Stimulants and growth in children with attention-deficit/hyperactivity disorder
}

\author{
Bianca Lee Negrao ${ }^{\mathrm{a}, *}$, Margaretha Viljoen ${ }^{\mathrm{b}}$ \\ ${ }^{a}$ Department of Human Anatomy and Physiology, Faculty of Health Sciences, University of Johannesburg, Private Bag X2, Suite 149, Dunswart 1508, South Africa \\ ${ }^{\mathrm{b}}$ Department of Physiology, School of Medicine, Faculty of Health Sciences, University of Pretoria, Box 2043, Pretoria 0001, South Africa
}

\section{A R T I C L E I N F O}

\section{Article history:}

Received 10 January 2011

Accepted 7 March 2011

Available online $\mathrm{xxxx}$

\begin{abstract}
A B S T R A C T
Initial suggestions that suppression of growth may be an intrinsic characteristic of attention-deficit/ hyperactivity disorder (ADHD) have now largely been disproven. Although controversy persists regarding the possible negative effect of adrenergic stimulants on growth in children with ADHD, the consensus that appears to be reached in the scientific literature is that stimulant usage may cause a manageable attenuation of growth in these children. Since it is known that stimulants increase the amount of dopamine and noradrenaline in the synapse, this writing suggests that these increases in dopamine and noradrenaline are responsible for the growth attenuation in these children. It appears that increased amounts of dopamine and noradrenaline have the ability to inhibit the secretion of growth hormone and growth-related hormones such as prolactin, thyroid hormones, sex hormones and insulin. Therefore, it would be reasonable to suggest that the increases in dopamine and noradrenaline caused by stimulant usage can disrupt the homeostasis of both growth hormone and growth-related hormones, generating the potential for the suppression of growth.
\end{abstract}

(ㄷ) 2011 Elsevier Ltd. All rights reserved.

\section{Introduction}

There is, as yet, no consensus on whether children with attention-deficit/hyperactivity disorder (ADHD), who are treated with adrenergic stimulants, experience growth inhibition, or not. In order to determine whether a relationship exists between stimulant intake and growth in children with ADHD, the first question to be asked is how un-medicated children with ADHD compare in size to control subjects. Although some studies found un-medicated children with ADHD to be of normal height [1-3], weight [1,2] and body mass index (BMI) $[2,4]$; several, in fact the majority, of studies indicated that un-medicated children with ADHD are actually taller [5-9] and heavier than normal $[3,5-8,10]$. These findings, therefore, contradict the initial suggestion [11] that height deficits in ADHD may be mediated by the disease itself.

Since the above-mentioned findings indicate that children with ADHD are generally average to above-average in height, weight and BMI, this suggests that growth retardation is not an intrinsic characteristic of ADHD. It, therefore, led to the next question, i.e. can the use of stimulant medication be associated with growth inhibition in children with ADHD? Although this topic is highly controversial, with some studies indicating that stimulant treatment has no effect on the growth of children with ADHD $[2,3,12,13]$; the overriding evidence in the scientific literature is that stimulant treatment can indeed cause an attenuation of growth. However, this problem seems to be manageable [5]. Most

\footnotetext{
* Corresponding author. Tel.: +27 11559 6250; fax: +27 115596558 .

E-mail address: bnegrao@uj.ac.za (B.L. Negrao).
}

studies agree that stimulant medication causes an attenuation of height velocity, specifically during the first few years of treatment [1,6-8,14-24], with an estimated height deficit of about $1 \mathrm{~cm} /$ year for the first 3 years [8]. Although some studies suggest that, in most cases, this stunting of linear growth normalises after approximately 3 years of treatment and that adults with ADHD do not differ significantly in height from control subjects [1,4,8,12,22], others are of the opinion that no tolerance to the height suppressant effects of stimulants develops [19] and no evidence of growth rebound exists in these subjects [6].

Regarding the effect of stimulant medication on weight, the consensus appears to be that adrenergic stimulants can cause a significant decrease in weight, specifically during the first few months of treatment $[3-8,10,14,15,19,21,22,24]$. However, this effect appears to be more pronounced in children that are over-weight to begin with $[10,12]$. Moreover, it is believed that the weight suppressant effects of stimulants decrease over time and that these children re-gain the weight loss in later years $[5,10,12,19,22]$.

Further indications regarding the relationship between stimulant usage and growth are that the effects of stimulant medication on growth are dosage dependent, with higher doses of stimulant medication causing greater growth deficits [5,19,21], and that amphetamines cause more growth suppression than methylphenidate $[19,22]$. However, it should be mentioned that the dosage dependent effects of stimulants on growth are not supported by all studies $[10,20]$. The effect of drug holidays on growth also remains controversial. Although there are some indications that drug holidays may reduce the potential growth-inhibitory effects of stimulants [19], scepticism regarding the effect of drug holidays 
still exists [3,14,25]. Pliszka et al. [25] specifically, found that drug holidays had no effect on change in height $\mathrm{z}$ scores in children with ADHD.

Since the overriding evidence is that stimulant medication has the potential to cause growth attenuation in children with ADHD, the question remains as to the possible mechanism/s by which stimulants may affect growth. Although the mechanism of action of the stimulants commonly used to treat ADHD, such as amphetamines and methylphenidate, is not completely understood, it is generally accepted that they function by increasing the amount of extracellular dopamine and noradrenaline in the synapse [26-29]. They accomplish this by increasing the efflux of dopamine into the synapse, with methylphenidate specifically shown to cause an increased transport of dopamine into vesicles [30] and, moreover, an increase in the release of dopamine from these vesicular stores [30,31].

Furthermore, stimulants also decrease the re-uptake of dopamine and noradrenaline $[28,29]$ by inhibiting dopamine and noradrenaline transporters [31-33], with high affinity [34]. Indeed, it has been shown in mice that enhanced dopaminergic neurotransmission is necessary for methylphenidate to exert its stimulating and rewarding effects, while enhanced noradrenergic neurotransmission is required to inhibit locomotor activity [34]. Areas in which methylphenidate-induced increases in dopamine have been shown to occur include the dorsal striatum [33], prefrontal cortex, nucleus accumbens and caudate-putamen [31]. Important receptors which appear to be involved in the therapeutic effects of methylphenidate in the prefrontal cortex include the noradrenergic $\alpha-2$ adrenoreceptors and dopamine D1 receptors [27]. Although it is believed that amphetamines function by increasing the extracellular concentration of noradrenaline, dopamine and serotonin, indications are that methylphenidate has no effect on extracellular serotonin [35]. Therefore, the focus in this writing will be on the effects of dopamine and noradrenaline on growth. The question then is what impact do increases in dopamine and noradrenaline have on the growth axis?

\section{Stimulants and growth hormone}

Growth hormone $(\mathrm{GH})$ stimulates protein synthesis in the body, resulting in enlargement of the skeleton, skeletal muscles and viscera. The effects of GH on skeletal growth are mediated by somatomedins produced by the liver such as insulin-like growth factor I (IGF-I) and insulin-like growth factor II (IGF-II) [36]. No recent studies which look at the effect of methylphenidate and related psychostimulants on GH could be found. Furthermore, older results on the effect of stimulant medication on GH secretion appear to be somewhat contradictory. Indications from a number of laboratories are that stimulant usage can cause a decrease in GH secretory activity [37-40], as well as a decrease in IGF levels [2,41]. A case study by Barter and Krammer [38] showed that methylphenidate is associated with suppression of sleep-induced GH release, while a case study by Holtkamp et al. [37] found a decrease in GH secretion in a child experiencing almost complete growth arrest following methylphenidate intake. Furthermore, Aarskog et al. [39] reported that methylphenidate results in a delayed $\mathrm{GH}$ response to L-3,4-dihydroxyphenylalanine (L-dopa), while Hunt et al. [40] found that methylphenidate causes a decreased $\mathrm{GH}$ response to the adrenergic agonist clonidine. Kilgore et al. [41], moreover, found that methylphenidate and related psychostimulants result in an inhibition of IGF bioactivity in cartilage tissue.

Although several studies indicated an inhibitory effect of stimulant medication on growth hormone and growth factor levels, some results are less supportive of the possibility. Indeed, a handful of older studies [42-44] have reported an increase in human GH levels with methylphenidate usage. Furthermore, Bereket et al. [2] reported methylphenidate to be associated with mild, but transient decreases in serum IGF-1 and IGF binding protein 3 (IGFBP-3) levels, while Toren et al. [45] found that boys with ADHD treated with methylphenidate do not differ from untreated boys, or from control subjects, with regards to fasting serum $\mathrm{GH}$, GH binding protein (GHBP) or IGF-1 levels. More than the absolute serum levels are necessary to be able to assess the influence of these stimulants on growth hormone functioning and, as yet, not much has been done in this respect.

Since a relatively limited number of studies are available on the effects of dopamine and noradrenaline on growth hormone secretion in subjects with ADHD, the effects of these hormones on $\mathrm{GH}$ secretion in subjects other than individuals with ADHD is summarised in Table 1 . The majority of studies have found that dopamine causes a decrease in GH concentrations [44-48,52]. In animals, dopamine has been found to decrease the secretion of GH by pituitary cells due to an increase in the release of somatostatin [5759]. Similarly, it has been suggested that the increase in dopamine caused by stimulant administration in humans leads to a decrease in GH secretion [5] due to its effect on D2 dopamine receptors [60], which may have a direct inhibitory action on somatotropes [46].

Regarding the effect of an increase in noradrenaline on $\mathrm{GH}$ secretion, it has been shown that, in goldfish, noradrenaline decreases the release of GH due to its effect on $\alpha-2$ adrenoreceptors [61]. Interestingly, this effect was found to be dosage dependent and reversible [61]. Although quite a far stretch, if extrapolated to humans, this could provide a possible explanation for the perception that an increase in stimulant dosage causes greater growth deficits, as well as the belief that discontinuation of stimulant usage leads to a surge in growth [62]. In humans, it has been found that stimulation of $\alpha-2$ adrenoreceptors can exert a dual effect on GH by either inhibiting [55] or stimulating its release [53,54,63]. Furthermore, it has been shown that stimulation of $\beta$-receptors can inhibit GH release via stimulation of hypothalamic somatostatin [63].

The overriding evidence therefore supports the potential of stimulant medication to inhibit growth via its effects on $\mathrm{GH}$, be it directly on its secretion or on the somatomedins or via cellular actions. Therefore, it would appear that increases in both dopamine and noradrenaline have the potential to decrease $\mathrm{GH}$-related functions. This could result in a decreased enlargement of the skeleton, skeletal muscles and viscera and would, therefore, cause decreases in both height and weight gain.

\section{Stimulants and prolactin}

Besides its effects on mammary development and lactogenesis, prolactin is believed to act as an autocrine/paracrine cytokine or growth factor [64], with stimulatory effects on cellular growth and proliferation believed to resemble those of GH [65]. These effects appear to be mediated by an intermediary growth molecule called synlactin, which is synthesised and released by the liver [65]. Although the effect of synlactin on growth in humans has not been documented, synlactin has been associated with cropsac mucosal growth in rats, mice and pigeons [66], and a substantial increase in the height of the tail fin in bullfrog tadpoles [67]. Furthermore, a non-lactogenic factor believed to be related to synlactin, which has been shown to synergistically enhance the growth of rat lymphoma cells, has been found in human serum [68].

It is interesting to note that a correlation $(r=0.88)$ between suppression of growth in stature and prolactin levels was found in a study on hyperkinetic children [1], while a highly significant correlation between loss of expected height percentile and reductions in mean sleep-related prolactin secretion was found in a 
Table 1

The effect of dopamine and noradrenaline on growth hormone levels.

\begin{tabular}{|c|c|c|c|c|c|}
\hline \multicolumn{3}{|c|}{ Effect of dopamine on GH } & \multicolumn{3}{|c|}{ Effect of noradrenaline on $\mathrm{GH}$} \\
\hline Author & Effect & Subjects & Author & Effect & Subjects \\
\hline $\begin{array}{l}\text { Van den Berghe } \\
\text { et al. [46] }\end{array}$ & $\begin{array}{l}\text { Dopamine decreases mean serum GH } \\
\text { concentrations, mean secretion rate, } \\
\text { amount of GH per secretory burst and } \\
\text { secretory burst amplitude } \\
\text { After dopamine withdrawal, } \\
\text { increased GH secretion is detected }\end{array}$ & $\begin{array}{l}\text { Critically ill adult } \\
\text { polytrauma patients } \\
(n=11)\end{array}$ & $\begin{array}{l}\text { Durá Travé } \\
\text { et al. [53] }\end{array}$ & $\begin{array}{l}\alpha-2 \text { Adrenergic agonists clonidine } \\
\text { and guanfacine increase the release of } \\
\text { GH in } 82.4 \% \text { and } 47 \% \text { of cases } \\
\text { respectively }\end{array}$ & $\begin{array}{l}\text { Children with short } \\
\text { stature }(n=17)\end{array}$ \\
\hline Svoboda et al. [47] & $\begin{array}{l}\text { Dopamine agonist CV 205-502 } \\
\text { decreases plasma GH concentrations }\end{array}$ & $\begin{array}{l}\text { Patients with acromegaly } \\
(n=10)\end{array}$ & $\begin{array}{l}\text { Hoehe et al. } \\
{[54]}\end{array}$ & $\begin{array}{l}\alpha-2 \text { Adrenergic agonist clonidine } \\
\text { induces a significant dose-dependent } \\
\text { GH increase }\end{array}$ & $\begin{array}{l}\text { Healthy male } \\
\text { volunteers }(n=12)\end{array}$ \\
\hline $\begin{array}{l}\text { De Zegher et al. } \\
\text { [48] }\end{array}$ & $\begin{array}{l}\text { Dopamine virtually abolishes GH } \\
\text { secretion } \\
\text { Dopamine withdrawal is associated } \\
\text { with a rebound release of GH } \\
\text { Dopamine withdrawal causes a } \\
\text { median 3-fold increase of GH levels }\end{array}$ & 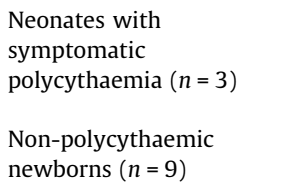 & $\begin{array}{l}\text { Struthers } \\
\text { et al. [55] }\end{array}$ & $\begin{array}{l}\alpha-2 \text { Adrenergic antagonist (idazoxan) } \\
\text { augments the exercise-induced } \\
\text { increase in } \mathrm{GH}\end{array}$ & $\begin{array}{l}\text { Normal volunteers } \\
(n=6)\end{array}$ \\
\hline Miell et al. [49] & $\begin{array}{l}\text { Dopaminergic agonist CV 205-502 } \\
\text { causes an increase in GH secretion }\end{array}$ & $\begin{array}{l}\text { Healthy, male volunteers } \\
(n=18)\end{array}$ & $\begin{array}{l}\text { Lechin } \\
\text { et al. [56] }\end{array}$ & $\begin{array}{l}\alpha-2 \text { Adrenergic agonist clonidine } \\
\text { induces no changes in GH levels }\end{array}$ & $\begin{array}{l}\text { Patients with } \\
\text { depression }(n=50)\end{array}$ \\
\hline $\begin{array}{l}\text { Boesgaard et al. } \\
\text { [50] }\end{array}$ & $\begin{array}{l}\text { Dopamine D1 receptor agonist } \\
\text { fenoldopam causes no change in } \\
\text { basal GH levels }\end{array}$ & Normal men $(n=9)$ & & & \\
\hline Ferrari et al. [51] & $\begin{array}{l}\text { Potent, dopaminergic agent } \\
\text { dihydroergokryptine does not affect } \\
\text { GH levels }\end{array}$ & Healthy women $(n=6)$ & & & \\
\hline \multirow[t]{2}{*}{ Camanni et al. [52] } & $\begin{array}{l}\text { Dopamine fails to induce an increase } \\
\text { in plasma GH }\end{array}$ & Normal subjects $(n=9)$ & & & \\
\hline & Dopamine causes a marked fall in $\mathrm{GH}$ & $\begin{array}{l}\text { Patients with acromegaly } \\
(n=15)\end{array}$ & & & \\
\hline
\end{tabular}

GH, growth hormone.

study by Puig-Antich et al. [69] on hyperkinetic children taking stimulants.

Dopamine is a well known prolactostatin which inhibits prolactin secretion [51,70-83], as well as the prolactin response to thyroid releasing hormone (TRH) [84-86]. It has been shown that slight elevations of plasma dopamine are sufficient to inhibit prolactin secretion, suggesting that dopamine is a major physiological prolactin-inhibiting factor [80]. The effect of dopamine on prolactin is believed to be due to the direct inhibition of the high-secretory tone of the anterior pituitary lactotroph [87]. This is believed to be due to the binding of dopamine to D2 receptors, which results in a reduction in prolactin gene expression and exocytosis through intracellular signaling mechanisms [87]. D1 receptor stimulation, on the other hand, has been shown to increase prolactin levels $[50,88,89]$. Although not much research has been done into the effect of noradrenaline on prolactin release, it has been shown that noradrenaline causes prolactin suppression in both adenomatous and nonadenomatous pituitary cells [60], and that it decreases prolactin secretion via ovine pituitary cell adrenoreceptors [90]. However, unlike dopamine, noradrenaline is believed not to be a physiologically important prolactin-inhibiting factor [90].

Therefore, increases in dopamine and noradrenaline both have the potential to exert an inhibitory effect on prolactin secretion, resulting in a deficiency in prolactin-related cellular growth functions.

\section{Stimulants and thyroid hormones}

The main function of the thyroid hormones is the stimulation of cellular metabolism, which in itself can have an effect on the physical characteristics of the body. Direct effects of thyroid hormones on growth include the stimulation of endochondral ossification, linear bone growth, maturation of epiphyseal bone centres and an increase in the maturation and activity of chondrocytes in the cartilage growth plate [65].

Although not much work has been done on the effect of stimulants on thyroid hormone secretion, stimulant medication has been shown to cause a statistically significant drop in thyroxine (T4) in children with ADHD [2]. Similarly, repeated amphetamine exposure has been shown to cause a decrease in rat plasma T4 levels [91]. Regarding the effect of dopamine on thyroid hormones (see Table 2), studies have shown that dopamine decreases the levels of thyroid stimulating hormone (TSH) in the body [50,82,92,93], and causes a suppression of thyroidal iodine release and serum T4 and triiodothyronine (T3) levels [93]. Moreover, it appears that dopamine infusion decreases the response of TSH [84-86,94] and T3 [84] to TRH. Some studies suggest that dopamine inhibits TSH at the hypothalamic level [50], while others suggest that there is a direct inhibition of pituitary TSH with a secondary effect on thyroid gland secretion [93].

Therefore, it would appear that the increase in dopamine caused by stimulant usage could very well result in an attenuation of thyroid hormone release and thereby a stunting of growth. The inhibitory effect of stimulants on thyroid functioning, as mentioned before, has already been shown $[2,91]$.

\section{Stimulants and sex hormones}

Testosterone stimulates protein synthesis and, therefore, muscular development and is, moreover, involved in the stimulation of linear or skeletal growth [95]. Similarly, oestrogen is responsible for protein synthesis and is also involved in skeletal growth and the maintenance of the structural integrity of the skeletal system [95]. The release of testosterone and oestrogen is controlled by lutropin (LH), which in turn is regulated by hypothalamic luliberin or gonadotropin releasing hormone (GnRH) [95]. 
Table 2

The effect of dopamine on thyroid hormone levels.

\begin{tabular}{|c|c|c|}
\hline Author & Effect & Subjects \\
\hline $\begin{array}{l}\text { Van den Berghe } \\
\text { et al. [84] }\end{array}$ & $\begin{array}{l}\text { Dopamine decreases the } \\
\text { response of TSH and T3 to } \\
\text { TRH }\end{array}$ & $\begin{array}{l}\text { Critically ill patients } \\
(n=15)\end{array}$ \\
\hline $\begin{array}{l}\text { De Zegher et al. } \\
{[92]}\end{array}$ & $\begin{array}{l}\text { Dopamine inhibits the } \\
\text { release of TSH }\end{array}$ & Neonates \\
\hline $\begin{array}{l}\text { Boesgaard et al. } \\
\text { [50] }\end{array}$ & $\begin{array}{l}\text { Dopamine D1 receptor } \\
\text { agonist fenoldopam } \\
\text { causes a decrease in basal } \\
\text { TSH }\end{array}$ & Normal men $(n=9)$ \\
\hline Connell et al. [86] & $\begin{array}{l}\text { Dopamine decreases the } \\
\text { response of TSH to TRH }\end{array}$ & Normal males $(n=6)$ \\
\hline Kaptein et al. [93] & $\begin{array}{l}\text { Dopamine infusion causes } \\
\text { a suppression of thyroidal } \\
\text { iodine release, serum TSH, } \\
\text { serum T3 and serum T4 }\end{array}$ & $\begin{array}{l}\text { Healthy euthyroid males } \\
(n=6)\end{array}$ \\
\hline $\begin{array}{l}\text { Köbberling et al. } \\
\text { [94] }\end{array}$ & $\begin{array}{l}\text { Dopamine agonist } \\
\text { bromocriptine does not } \\
\text { alter the TSH response to } \\
\text { TRH at } 100 \mu \mathrm{g} \text {, but } \\
\text { significantly blunts it after } \\
200 \mu \mathrm{g}\end{array}$ & Normal volunteers $(n=6)$ \\
\hline Massara et al. [82] & $\begin{array}{l}\text { Dopamine decreases TSH } \\
\text { levels }\end{array}$ & $\begin{array}{l}\text { Normal subjects }(n=5) \text {, } \\
\text { women with galactorrhea } \\
(n=7) \text {, patients with } \\
\text { acromegaly }(n=9) \text { and } \\
\text { patients with primary } \\
\text { hypothyroidism }(n=4)\end{array}$ \\
\hline Besses et al. [85] & $\begin{array}{l}\text { Dopamine decreases the } \\
\text { response of TSH to TRH }\end{array}$ & Normal males $(n=10)$ \\
\hline
\end{tabular}

TSH, thyroid stimulating hormone; T3, triiodothyronine; TRH, thyroid releasing hormone; T4, thyroxine.

With regards to the effect of the sex hormones on GH secretion, oestrogen has been found to cause increases in the pulsatile secretion of GH in healthy women [96], while testosterone is believed to stimulate the $\mathrm{GH}$-axis at the hypothalamic level by promoting $\mathrm{GH}$ releasing hormone (GHRH) functioning in adult men [97]. Furthermore, testosterone has been shown to cause an increase in nocturnal $\mathrm{GH}$ concentration and pulsatile $\mathrm{GH}$ secretion, as well as morning serum IGF-1 levels in healthy older men [98].

Indications are that methylphenidate can flatten testosterone diurnal rhythms in children [99] and markedly decrease levels of rat testicular [100], as well as plasma [101], testosterone. Repeated amphetamine administration, similarly, has been shown to cause decreases in basal $[91,101,102]$ and human chorionic gonadotropin-stimulated levels of testosterone in rats [102]. With regards to oestrogen, indications from studies on rats are that methylphenidate can adversely affect ovarian folliculogenesis, perturb pubertal onset and adversely affect maturation of the female reproductive axis by inhibiting pituitary LH release [103].

Studies show that dopamine inhibits the release of $\mathrm{LH}$ $[70,73,74,104,106-110]$, as well as the LH response to GnRH [105] (see Table 3). Furthermore, the D1 receptor agonist fenoldopam has been shown to cause a decrease in basal and stimulated testosterone [50] (see Table 3).

The increase in dopamine concentration, caused by stimulant usage, could therefore result in decreases in both testosterone and oestrogen production, which in turn would lead to decreases in both muscle synthesis and skeletal growth, resulting in both decreases in weight and height gain. In addition, the decreases in testosterone and oestrogen production would then result in a decrease in GH secretion, accentuating the already present growth attenuation.

\section{Stimulants and insulin}

Insulin supports growth via its stimulation of amino acid absorption and protein synthesis, as well as lipogenesis $[111,112]$. Since insulin is required for protein synthesis, it is believed to be as essential for growth as GH itself [113].

The effect of methylphenidate and related psychostimulants on insulin secretion is not well documented and, moreover, results from existing studies appear to be contradictory. Some studies suggest that methylphenidate and amphetamine cause decreases in plasma insulin levels in rats [114], while others indicate that amphetamine increases rat and mice plasma [115] and rat cerebral insulin concentrations [116], and still others suggest that amphet-

Table 3

The effect of dopamine on the sex hormones.

\begin{tabular}{|c|c|c|c|}
\hline Hormone & Author & Effect & Subjects \\
\hline \multirow[t]{11}{*}{ 1. Lutropin (LH) } & Van den Berghe et al. [104] & $\begin{array}{l}\text { Dopamine decreases mean serum LH concentration, LH } \\
\text { secretory amplitude, amount of LH secreted per burst } \\
\text { and the number of LH pulses }\end{array}$ & Adult male polytrauma patients $(n=9)$ \\
\hline & Boesgaard et al. [50] & $\begin{array}{l}\text { Dopamine D- } 1 \text { receptor agonist fenoldopam increases } \\
\text { the } \mathrm{LH} \text { response to } \mathrm{GnRH}\end{array}$ & Normal men $(n=9)$ \\
\hline & Martin et al. [71] & $\begin{array}{l}\text { Low doses of dopamine do not achieve a significant } \\
\text { suppression of LH release }\end{array}$ & $\begin{array}{l}\text { Euprolactinemic }(n=15) \text { and hyperprolactinemic } \\
(n=15) \text { women }\end{array}$ \\
\hline & Nicoletti et al. [105] & $\begin{array}{l}\text { Dopamine causes no suppression of serum gonadotropin } \\
\text { levels but reduces the LH response to GnRH }\end{array}$ & Normal and amenorrheic hyperprolactinemic women \\
\hline & Barnes et al. [106] & Dopamine causes a significant decrease in LH levels & Ovulatory women $(n=15)$ \\
\hline & Paradisi et al. [73] & $\begin{array}{l}\text { Dopamine produces a significant decrease in serum LH } \\
\text { levels }\end{array}$ & Subjects with polycystic ovarian disease $(n=6)$ \\
\hline & Foresta et al. [107] & Dopamine decreases LH levels & Castrated men $(n=4)$ and normal men $(n=4)$ \\
\hline & Ferrari et al. [108] & Dopamine causes a significant reduction in LH levels & $\begin{array}{l}\text { Healthy women }(n=8) \text {, patients with } \\
\text { hyperprolactinaemic amenorrhea }(n=12) \text {, patients with } \\
\text { premature ovarian failure }(n=5) \text { and patients with } \\
\text { polycystic ovarian disease }(n=8)\end{array}$ \\
\hline & Martin et al. [70] & $\begin{array}{l}\text { Dopamine lowers circulating LH levels and reduces } \\
\text { spontaneous LH fluctuations }\end{array}$ & Normal ovulatory women \\
\hline & Quigley et al. [109] & Dopamine suppresses elevated LH levels & Patients with polycystic ovarian syndrome $(n=8)$ \\
\hline & Judd et al. [110] & Dopamine decreases levels of LH & Ovariectomized and normal women \\
\hline 2. Testosterone & Boesgaard et al. [50] & $\begin{array}{l}\text { Dopamine D-1 receptor agonist fenoldopam causes a } \\
\text { decrease in basal and stimulated testosterone }\end{array}$ & Normal men $(n=9)$ \\
\hline
\end{tabular}

GnRH, gonadotropin releasing hormone. 
Table 4

The effect of dopamine and noradrenaline on insulin.

\begin{tabular}{|c|c|c|c|c|c|}
\hline \multicolumn{3}{|c|}{ Effect of dopamine on insulin } & \multicolumn{3}{|c|}{ Effect of noradrenaline on insulin } \\
\hline Author & Effect & Subjects & Author & Effect & Subjects \\
\hline $\begin{array}{l}\text { De Leeuw van Weenen } \\
\text { et al. [118] }\end{array}$ & $\begin{array}{l}\text { Dopamine } \mathrm{D} 2 \text { receptor agonist } \\
\text { bromocriptine inhibits glucose-stimulated } \\
\text { insulin release }\end{array}$ & $\begin{array}{l}\text { C57B16/J mice and INS-1E beta } \\
\text { cells }\end{array}$ & $\begin{array}{l}\text { Walters } \\
\text { et al. } \\
{[122]}\end{array}$ & $\begin{array}{l}\text { Noradrenaline results } \\
\text { in a reduced mean } \\
\text { second-phase insulin } \\
\text { secretion rate }\end{array}$ & $\begin{array}{l}\text { Patients with } \\
\text { non-insulin- } \\
\text { dependent } \\
\text { diabetes mellitus } \\
(n=8)\end{array}$ \\
\hline Jones et al. [119] & $\begin{array}{l}\text { Dopamine inhibits basal and glucose- } \\
\text { induced insulin secretion }\end{array}$ & In vitro perifusion system & $\begin{array}{l}\text { Porte } \\
\text { and } \\
\text { Williams } \\
{[123]}\end{array}$ & $\begin{array}{l}\text { Noradrenaline } \\
\text { inhibits the release of } \\
\text { insulin }\end{array}$ & $\begin{array}{l}\text { Healthy adults } \\
(n=10)\end{array}$ \\
\hline Shankar et al. [120] & $\begin{array}{l}\text { Low concentrations of dopamine increase } \\
\text { glucose-induced insulin secretion, while high } \\
\text { concentrations of dopamine inhibit glucose- } \\
\text { induced insulin secretion } \\
\text { Noradrenaline can inhibit the stimulatory } \\
\text { effects of low doses of dopamine on insulin } \\
\text { secretion }\end{array}$ & Pancreatic islets in vitro & & & \\
\hline Rubi et al. [121] & $\begin{array}{l}\text { Dopamine and D2 receptor agonist } \\
\text { quinpirole inhibit glucose-stimulated insulin } \\
\text { secretion }\end{array}$ & $\begin{array}{l}\text { INS-1E beta cells, fluorescence- } \\
\text { activated cell-sorted primary rat } \\
\text { beta cells, pancreatic islets of rat, } \\
\text { mouse and human origin }\end{array}$ & & & \\
\hline
\end{tabular}

amine causes no discernable changes in rat plasma insulin levels [117].

Studies show that dopamine and its agonists inhibit glucosestimulated insulin release [118-121] (see Table 4). Although this effect was initially believed to be mediated via D2 receptors [119-121], a recent study by de Leeuw van Weenen et al. [118] has indicated that the inhibitory effect of dopamine on insulin release is actually mediated via pancreatic $\alpha-2$ adrenoreceptors. Although a study by Shankar et al. [120] found that low concentrations of dopamine increase the secretion of insulin, it is interesting to note that, in addition, this study found that noradrenaline can then inhibit dopamine's stimulatory effects on insulin secretion. Noradrenaline itself is, moreover, believed to be a major physiological inhibitor of insulin secretion [122-124]. Indications are that noradrenaline acts via pertussis toxin-sensitive $G$ proteins, thereby activating protein acyltransferase, which results in acylation and therefore inhibition, of proteins critical to the exocytosis of insulin [124].

Increases in both dopamine and noradrenaline concentrations, due to stimulant usage, could therefore result in decreases in basal and glucose-stimulated insulin release, contributing to the inhibition of amino acid absorption, protein synthesis, lipogenesis and growth.

\section{Discussion}

It is fairly obvious that adrenergic stimulants can influence most hormones involved in the growth process, with growth hormone possibly playing a central role. This would be in line with writing by Poulton [22] suggesting that stimulants activate mechanisms adapted for acute starvation in order to conserve energy stores and that the resultant negative energy balance could lead to a decrease in growth.

Although the situation is generally not of major concern, there do appear to be cases where the effects of stimulants on growth are significant. Such as in the study by Gross [12], where 2 patients experienced a substantial deficit in expected height while on stimulant medication, and in the study by Millichap [13] where 2 out of the 36 boys studied experienced a significantly decreased rate of growth. It appears that "there may be an important subgroup whose growth is permanently attenuated" [22]. We are thus left with the question as to which risk factors determine whether a child will be affected.

In summary we can say that stimulants appear to have the ability to cause an attenuation of growth in height and weight by increasing the amount of noradrenaline and dopamine in the synapse. We hypothesize that dopamine and noradrenaline may attenuate growth by affecting growth hormone activity and possibly that of other growth-related hormones such as prolactin, thyroid hormones, sex hormones and insulin. Furthermore, these growth-related hormones could very well have an additional influence through their effect on growth hormone itself.

\section{Clinical implications}

- Although growth suppression appears to occur in a minority of children taking adrenergic stimulants, it is necessary that clinicians are aware of the possibility.

- Until otherwise proven, clinicians should be aware of indications that increases in dopamine and noradrenaline could result in decreases in basal and glucose-stimulated insulin release, and may therefore influence glucose metabolism.

- Stimulants prescribed for individuals with ADHD may have a far more comprehensive effect on the endocrine system, and therefore on the internal homeostasis, of these individuals than is generally assumed.

\section{Limitations of the study}

A number of questions could not be answered, including:

- Whether drug holidays have an effect on growth, and if so, what the effect is.

- Which risk factors determine whether growth will be affected by stimulant usage.

\section{Conflicts of interest statement}

The authors declare that there is no conflict of interest. 


\section{References}

[1] Roche AF, Lipman RS, Overall JE, Hung W. The effects of stimulant medication on the growth of hyperkinetic children. Pediatrics 1979;63(6):847-50.

[2] Bereket A, Turan S, Karaman MG, Haklar G, Ozbay F, Yazgan MY. Height, weight, IGF-1, IGFBP-3 and thyroid functions in prepubertal children with attention deficit hyperactivity disorder: effect of methylphenidate treatment. Horm Res 2005;63:159-64.

[3] Spencer TJ, Faraone SV, Biederman J, et al. Does prolonged therapy with a long-acting stimulant suppress growth in children with ADHD? J Am Acad Child Adolesc Psychiatry 2006;45(5):527-37.

[4] Zachor DA, Roberts AW, Hodgens JB, Isaacs JS, Merrick J. Effects of long-term psychostimulant medication on growth of children with ADHD. Res Dev Disabil 2006;27:162-74

[5] Faraone SV, Biederman J, Morley CP, Spencer TJ. Effect of stimulants on height and weight: a review of the literature. J Am Acad Child Adolesc Psychiatry 2008;47(9):994-1009.

[6] Swanson JM, Elliott GR, Greenhill LL, et al. Effects of stimulant medication on growth rates across 3 years in the MTA follow-up. J Am Acad Child Adolesc Psychiatry 2007;46(8):1015-27.

[7] Swanson J, Greenhill L, Wigal T, et al. Stimulant-related reductions of growth rates in the PATS. J Am Acad Child Adolesc Psychiatry 2006;45(11):1304-13.

[8] Poulton A, Cowell CT. Slowing of growth in height and weight on stimulants: a characteristic pattern. J Paediatr Child Health 2003;39:180-5.

[9] MTA Cooperative Group. National Institute of Mental Health multimodal treatment study of ADHD follow-up: changes in effectiveness and growth after the end of treatment. Pediatrics 2004;113(4):762-9.

[10] Sund AM, Zeiner P. Does extended medication with amphetamine or methylphenidate reduce growth in hyperactive children? Nord J Psychiatry 2002;56(1):53-7.

[11] Spencer TJ, Biederman J, Harding M, O' Donnell D, Faraone SV, Wilens TE. Growth deficits in ADHD children revisited: evidence for disorder-associated growth delays? J Am Acad Child Adolesc Psychiatry 1996;35(11):1460-9.

[12] Gross MD. Growth of hyperkinetic children taking methylphenidate, dextroamphetamine, or imipramine/desipramine. Pediatrics 1976;58(3): 423-31.

[13] Millichap JG. Growth of hyperactive children treated with methylphenidate. J Learn Disabil 1978;11(9):567-70.

[14] Satterfield JH, Cantwell DP, Schell A, Blaschke T. Growth of hyperactive children treated with methylphenidate. Arch Gen Psychiatry 1979;36(2): 212-7.

[15] Loney J, Whaley-Klahn MA, Ponto LB, Adney K. Predictors of adolescent height and weight in hyperkinetic boys treated with methylphenidate [proceedings]. Psychopharmacol Bull 1981;17(1):132-4.

[16] Mattes JA, Gittelman R. Growth of hyperactive children on maintenance regimen of methylphenidate. Arch Gen Psychiatry 1983;40(3):317-21.

[17] Safer D, Allen R, Barr E. Depression of growth in hyperactive children on stimulant drugs. N Engl J Med 1972;287:217-20.

[18] Greenhill LL, Puig-Antich J, Novacenko H, et al. Prolactin, growth hormone and growth responses in boys with attention deficit disorder and hyperactivity treated with methylphenidate. J Am Acad Child Psychiatry 1984;23(1):58-67.

[19] Safer DJ, Allen RP. Factors influencing the suppressant effects of two stimulant drugs on the growth of hyperactive children. Pediatrics 1973;51(4):660-7.

[20] Zhang HY, Du ML, Zhuang SQ Liu MN. Influence of methylphenidate on growth of school age children with attention deficit hyperactivity disorder. Zhonghua Er Ke Za Zhi 2005;43(10):723-7.

[21] Faraone SV, Giefer EE. Long-term effects of methylphenidate transdermal delivery system treatment of ADHD on growth. J Am Acad Child Adolesc Psychiatry 2007;46(9):1138-47.

[22] Poulton A. Growth on stimulant medication; clarifying the confusion: a review. Arch Dis Child 2005;90:801-6.

[23] Lisska MC, Rivkees SA. Daily methylphenidate use slows the growth of children: a community based study. J Pediatr Endocrinol Metab 2003;16(5):711-8.

[24] Faraone SV, Spencer TJ, Kollins SH, Glatt SJ. Effects of lisdexamfetamine dimesylate treatment for ADHD on growth. J Am Acad Child Adolesc Psychiatry 2010;49(1):24-32.

[25] Pliszka SR, Matthews TL, Braslow KJ, Watson MA. Comparative effects of methylphenidate and mixed salts amphetamine on height and weight in children with attention-deficit/hyperactivity disorder. J Am Acad Child Adolesc Psychiatry 2006;45(5):520-6.

[26] Montgomery AJ, Asselin M, Farde L, Grasby PM. Measurement of methylphenidate-induced change in extrastriatal dopamine concentration using [ ${ }^{11}$ C]FLB 457 PET. J Cereb Blood Flow Metab 2007;27:369-77.

[27] Arnsten AFT, Dudley AG. Methylphenidate improves prefrontal cortical cognitive function through $\alpha 2$ adrenoceptor and dopamine D1 receptor actions: relevance to therapeutic effects in attention deficit hyperactivity disorder. Behav Brain Funct 2005;1(1):2.

[28] Carboni E, Silvagni A. Experimental investigations on dopamine transmission can provide clues on the mechanism of the therapeutic effect of amphetamine and methylphenidate in ADHD. Neural Plast 2004;11(1-2): 77-95.
[29] Vles JS, Feron FJ, Hendriksen JG, Jolles J, van Kroonenburgh MJ, Weber WE. Methylphenidate down-regulates the dopamine receptor and transporter system in children with attention deficit hyperkinetic disorder (ADHD). Neuropediatrics 2003;34(2):77-80.

[30] Volz TJ, Farnsworth SJ, Rowley SD, Hanson GR, Fleckenstein AE Methylphenidate-induced increases in vesicular dopamine sequestration and dopamine release in the striatum: the role of muscarinic and dopamine D2 receptors. J Pharmacol Exp Ther 2008;327(1):161-7.

[31] Russell V, de Villiers A, Sagvolden T, Lamm M, Taljaard J. Differences between electrically-, ritalin- and D-amphetamine-stimulated release of [3H]dopamine from brain slices suggest impaired vesicular storage of dopamine in an animal model of attention-deficit hyperactivity disorder Behav Brain Res 1998;94(1):163-71.

[32] Sandoval V, Riddle EL, Hanson GR, Fleckenstein AE. Methylphenidate redistributes vesicular monoamine transporter-2: role of dopamine receptors. J Neurosci 2002;22(19):8705-10.

[33] Volkow ND, Wang GJ, Fowler JS, et al. "Nonhedonic" food motivation in humans involves dopamine in the dorsal striatum and methylphenidate amplifies this effect. Synapse 2002;44(3):175-80.

[34] Tilley MR, Gu HH. The effects of methylphenidate on knockin mice with a methylphenidate-resistant dopamine transporter. J Pharmacol Exp Ther 2008;327(2):554-60

[35] Kuczenski R, Segal DS. Effects of methylphenidate on extracellular dopamine serotonin, and norepinephrine: comparison with amphetamine. J Neurochem 1997;68(5):2032-7.

[36] Haag M, Kruger MC [Endocrine system]. In: Meyer BJ, Van Papendorp DH, Meij HS, Viljoen M, editors. Human physiology. Pretoria: Juta; 2004. p. 18.1-18.67.

[37] Holtkamp K, Peters-Wallraf B, Wüller S, Pfäaffle R, Herpertz-Dahlmann B. Methylphenidate-related growth impairment. J Child Adolesc Psychopharmacol 2002;12(1):55-61.

[38] Barter M, Krammer H. Methylphenidate and growth retardation. JAMA 1978;239(17):1742-3.

[39] Aarskog D, Fevang FO, Klove H, Stoa KF, Thorsen T. The effect of the stimulant drugs, dextroamphetamine and methylphenidate, on secretion of growth hormone in hyperactive children. J Pediatr 1977;90(1):136-9.

[40] Hunt RD, Cohen DJ, Anderson G, Clark L. Possible change in noradrenergic receptor sensitivity following methylphenidate treatment: growth hormone and MHPG response to clonidine challenge in children with attention deficit disorder and hyperactivity. Life Sci 1984;35(8):885-97.

[41] Kilgore BS, Dickinson MA, Burnett CR, Lee J, Schedewie HK, Elders MJ Alterations in cartilage metabolism by neurostimulant drugs. J Pediatr 1979;94(4):542-5.

[42] Brown WA, Williams BW. Methylphenidate increases serum growth hormone concentrations. J Clin Endocrinol Metab 1976;43(4):937-9.

[43] Joyce PR, Donald RA, Nicholls MG, Livesey JH, Abbott RM. Endocrine and behavioural responses to methylphenidate in normal subjects. Biol Psychiatry 1986;21(11):1015-23.

[44] Shaywitz SE, Hunt RD, Jatlow P, et al. Psychopharmacology of attention deficit disorder: pharmacokinetic, neuroendocrine, and behavioral measures following acute and chronic treatment with methylphenidate. Pediatrics 1982;69(6):688-94.

[45] Toren P, Silbergeld A, Eldar S, et al. Lack of effect of methylphenidate on serum growth hormone (GH), GH-binding protein, and insulin-like growth factor I. Clin Neuropharmacol 1997;20(3):264-9.

[46] Van den Berghe G, de Zegher F, Lauwers P, Veldhuis JD. Growth hormone secretion in critical illness: effect of dopamine. J Clin Endocrinol Metab 1994;79(4):1141-6.

[47] Svoboda T, Kotzmann H, Clodi M, Bernecker P, Geyer G, Luger A. The non ergot D2-dopamine agonist CV 205-502 decreases growth hormone concentrations in acromegalic patients. Endocr Res 1994;20(1):59-63.

[48] De Zegher F, Van den Berghe G, Devlieger H, Eggermont E, Veldhuis JD. Dopamine inhibits growth hormone and prolactin secretion in the human newborn. Pediatr Res 1993;34(5):642-5.

[49] Miell JP, Pralong FP, Corder R, Gaillard RC. Stimulation of growth hormone release in man by the potent D2-dopamine agonist CV 205-502: comparison of responses to intravenous and oral administration. J Clin Endocrinol Metab 1990;71(6):1519-24

[50] Boesgaard S, Hagen C, Andersen AN, Eldrup E, Lange P. Effect of fenoldopam, a dopamine D-1 receptor agonist, on pituitary, gonadal and thyroid hormone secretion. Clin Endocrinol (Oxf) 1989;30(3):231-9.

[51] Ferrari C, Rampini P, Paracchi A, Boghen M, Mailland F. Effect of dihydroergokryptine administration on serum prolactin and growth hormone levels in normal, hyperprolactinaemic and acromegalic subjects: evidence of potent and long-lasting pituitary dopamine receptor stimulation Eur J Clin Pharmacol 1985;27(6):707-11.

[52] Camanni F, Massara F, Belforte L, Rosatello A, Molinatti GM. Effect of dopamine on plasma growth hormone and prolactin levels in normal and acromegalic subjects. J Clin Endocrinol Metab 1977;44(3):465-73.

[53] Durá Travé T, Juste Ruiz M, González Montero R, Gutiérrez Terán M, Mauri Dot M, Moya Benavent M. Sensitivity of the clonidine and guanfacine tests (alpha-2-adrenergic agonists) as pharmacologic stimulants of growth hormone. Effects on plasma cortisol. An Esp Pediatr 1996;45(6):575-8.

[54] Hoehe M, Valido G, Matussek N. Growth hormone, noradrenaline, blood pressure and cortisol responses to clonidine in healthy male volunteers: 
dose-response relations and reproducibility. Psychoneuroendocrinology 1988;13(5):409-18.

[55] Struthers AD, Burrin JM, Brown MJ. Exercise-induced increases in plasma catecholamines and growth hormone are augmented by selective alpha 2adrenoceptor blockade in man. Neuroendocrinology 1986;44(1):22-8

[56] Lechin F, van der Dijs B, Jakubowicz D, et al. Effects of clonidine on blood pressure, noradrenaline, cortisol, growth hormone, and prolactin plasma levels in high and low intestinal tone depressed patients. Neuroendocrinology 1985;41(2):156-62.

[57] Law GJ, Ray KP, Wallis M. Effects of growth hormone-releasing factor, somatostatin and dopamine on growth hormone and prolactin secretion from cultured ovine pituitary cells. FEBS Lett 1984;166(1):189-93.

[58] McMahon CD, Chapin LT, Lookingland KJ, Tucker HA. Stimulation of dopamine D1 receptors increases activity of periventricular somatostatin neurons and suppresses concentrations of growth hormone. Domest Anim Endocrinol 1998;15(4):257-65.

[59] Kentroti S, McCann SM. Role of dopamine in the inhibitory control of growth hormone and prolactin release by gastrin-releasing peptide. Brain Res Bull 1996;39(4):201-4.

[60] Ishibashi M, Yamaji T. Direct effects of catecholamines, thyrotropin-releasing hormone, and somatostatin on growth hormone and prolactin secretion from adenomatous and nonadenomatous human pituitary cells in culture. J Clin Invest 1984;73(1):66-78.

[61] Lee EKY, Chan VCC, Chang JP, Yunker WK, Wong AOL. Norepinephrine regulation of growth hormone release from goldfish pituitary cells. I Involvement of $\alpha 2$ adrenoreceptor and interactions with dopamine and salmon gonadotropin-releasing hormone. J Neuroendocrinol 2000; $12: 311-22$

[62] Safer DJ, Allen RP, Barr E. Growth rebound after termination of stimulant drugs. J Pediatr 1975;86(1):113-6.

[63] Muller EE, Locatelli V, Ghigo E, et al. Involvement of brain catecholamines and acetylcholine in growth hormone deficiency states. Pathophysiological, diagnostic and therapeutic implications. Drugs 1991;41(2):161-77.

[64] Keeler C, Jablonski EM, Albert YB, et al. The kinetics of binding human prolactin, but not growth hormone, to the prolactin receptor vary over a physiologic $\mathrm{pH}$ range. Biochemistry 2007;46(9):2398-410.

[65] Genuth SM [The endocrine system]. In: Berne RM, Levy MN, editors. Physiology. St. Louis: Mosby; 1998. p. 779-1011.

[66] Mick CC, Nicoll CS. Prolactin directly stimulates the liver in vivo to secrete a factor (synlactin) which acts synergistically with the hormone. Endocrinology 1985;116(5):2049-53.

[67] Delidow BC, Baldocchi RA, Nicoll CS. Evidence for hepatic involvement in the regulation of amphibian development by prolactin. Gen Comp Endocrinol 1988;70(3):418-24.

[68] McNeilly AS, Friesen HG. Presence of a nonlactogenic factor in human serum which synergistically enhances prolactin-stimulated growth of $\mathrm{Nb2}$ rat lymphoma cells in vitro. J Clin Endocrinol Metab 1985;61(3):408-11.

[69] Puig-Antich J, Greenhill LL, Sassin J, Sachar EJ. Growth hormone, prolactin and cortisol responses and growth patterns in hyperkinetic children treated with dextro-amphetamine: preliminary findings. J Am Acad Child Psychiatry 1978;17(3):457-75.

[70] Martin WH, Rogol AD, Kaiser DL, Thorner MO. Dopaminergic mechanisms and luteinizing hormone (LH) secretion. II. Differential effects of dopamine and bromocriptine on LH release in normal women. J Clin Endocrinol Metab 1981;52(4):650-6

[71] Martin MC, Monroe SE, Weiner RI, Jaffe RB. Low-dose dopamine infusions do not ablate luteinizing hormone pulses in women. Am J Obstet Gynecol 1988;159(4):898-903.

[72] Harrison RF, Synnott M, O' Moore R, O' Moore M. Can women with gonadotropin levels diagnostic of polycystic ovarian syndrome benefit from therapy with dopamine agonists? Ann NY Acad Sci 1993;687:272-9.

[73] Paradisi R, Margrini O, Venturoli S, et al. Naloxone does not interfere with the dopamine-induced decrease in gonadotropin secretion in women with polycytic ovarian disease. Horm Metab Res 1985;17(1):29-31.

[74] Judd SJ, Rakoff JS, Yen SS. Inhibition of gonadotropin and prolactin release by dopamine: effect of endogenous estradiol levels. J Clin Endocrinol Metab 1978;47(3):494-8.

[75] Kontogeorgos G, Horvath E, Kovacs K, et al. Morphologic changes of prolactinproducing pituitary adenomas after short treatment with dopamine agonists. Acta Neuropathol 2006;111(1):46-52.

[76] Schilling T, Gründling M, Strang CM, Möritz KU, Siegmund W, Hachenberg T. Effects of dopexamine, dobutamine or dopamine on prolactin and thyreotropin serum concentrations in high-risk surgical patients. Intensive Care Med 2004;30(6):1127-33.

[77] Bailey AR, Burchett KR. Effect of low-dose dopamine on serum concentrations of prolactin in critically ill patients. Br J Anaesth 1997;78(1):97-9.

[78] Schlegel S, Schlösser R, Hiemke C, Nickel O, Bockisch A, Hahn K. Prolactin plasma levels and D2-dopamine receptor occupancy measured with IBZMSPECT. Psychopharmacology (Berl) 1996;124(3):285-7.

[79] Rotrosen J, Angrist B, Clark C, Gershon S, Halpers FS, Sachar EJ. Suppression of prolactin by dopamine agonists in schizophrenics and controls. Am J Psychiatry 1978;135(8):949-51.

[80] Serri O, Kuchel O, Buu NT, Somma M. Differential effects of a low dose dopamine infusion on prolactin secretion in normal and hyperprolactinemic subjects. J Clin Endocrinol Metab 1983;56(2):255-9.
[81] Melis GB, Paoletti AM, Mais V, Fioretti P. Interference of dopamine infusion on gamma-amino butyric acid (GABA)-stimulated prolactin increase. J Endocrinol Invest 1980;3(4):445-8.

[82] Massara F, Camanni F, Vergano V, Belforte L, Molinatti GM. Inhibition of thyrotropin and prolactin secretion by dopamine in man. J Endocrinol Invest 1978;1(1):25-30.

[83] McPherson H, Walsh A, Silverstone T. Growth hormone and prolactin response to apomorphine in bipolar and unipolar depression. J Affect Disord 2003;76(1-3):121-5.

[84] Van den Berghe G, de Zegher F, Vlasselaers D, et al. Thyrotropin-releasing hormone in critical illness: from a dopamine-dependent test to a strategy for increasing low serum triiodothyronine, prolactin, and growth hormone concentrations. Crit Care Med 1996;24(4):590-5.

[85] Besses GS, Burrow GN, Spaulding SW, Donabedian RK. Dopamine infusion acutely inhibits the TSH and prolactin response to TRH. J Clin Endocrinol Metab 1975;41(5):985-8.

[86] Connell JM, Ball SG, Balmforth AJ, Beastall GH, Davies DL. Effect of low-dose dopamine infusion on basal and stimulated TSH and prolactin concentrations in man. Clin Endocrinol (Oxf) 1985;23(2):185-92.

[87] Fitzgerald P, Dinan TG. Prolactin and dopamine: what is the connection? A review article. J Psychopharmacol 2008;22(Suppl 2):12-9.

[88] Boesgaard S, Hagen C, Hangaard J, Andersen AN, Eldrup E. Pulsatile gonadotropin secretion and basal prolactin levels during dopamine D-1 receptor stimulation in normal women. Fertil Steril 1991;55(2):281-6.

[89] Fabbrini G, Braun A, Mouradian MM, Tamminga CA, Chase TN. Dopamine D-1 receptor agonist stimulation of prolactin secretion in man. J Neural Transm 1988;71(3):159-63.

[90] Colthorpe KL, Nalliah J, Anderson ST, Curlewis JD. Adrenoceptor subtype involvement in suppression of prolactin secretion by noradrenaline. J Neuroendocrinol 2000;12(4):297-302.

[91] Budziszewska B, Jaworska-Feil L, Lasoń W. The effect of repeated amphetamine and cocaine administration on adrenal, gonadal and thyroid hormone levels in the rat plasma. Exp Clin Endocrinol Diabetes 1996;104(4):334-8.

[92] de Zegher F, Van den Berghe G, Dumoulin M, Gewillig M, Daenen W, Devlieger H. Dopamine suppresses thyroid-stimulating hormone secretion in neonatal hypothyroidism. Acta Paediatr 1995;84(2):213-4

[93] Kaptein EM, Spencer CA, Kamiel MB, Nicoloff JT. Prolonged dopamine administration and thyroid hormone economy in normal and critically ill subjects. J Clin Endocrinol Metab 1980;51(2):387-93.

[94] Köbberling J, Darragh A, Del Pozo E. Chronic dopamine receptor stimulation using bromocriptine: failure to modify thyroid function. Clin Endocrinol (Oxf) 1979;11(4):367-70.

[95] Meyer BJ, Van Papendorp DH, Meij HS, Viljoen M [The reproductive systems]. In: Meyer BJ, Van Papendorp DH, Meij HS, Viljoen M, editors. Human physiology. Pretoria: Juta; 2004. p. 19.1-19.25.

[96] Veldhuis JD, Hudson SB, Erickson D, Bailey JN, Reynolds GA, Bowers CY. Relative effects of estrogen, age, and visceral fat on pulsatile growth hormone secretion in healthy women. Am J Physiol Endocrinol Metab 2009;60(2):E367-74.

[97] Bondanelli M, Ambrosio MR, Margutti A, Franceschetti P, Zatelli MC, Degli Uberti EC. Activation of the somatotropic axis by testosterone in adult men: evidence for a role of hypothalamic growth hormone-releasing hormone. Neuroendocrinology 2003;77(6):380-7.

[98] Muniyappa R, Sorkin JD, Veldhuis JD, et al. Long-term testosterone supplementation augments overnight growth hormone secretion in healthy older men. Am J Physiol Endocrinol Metab 2007;56(3):E769-75.

[99] Hibel LC, Granger DA, Cicchetti D, Rogosch F. Salivary biomarker levels and diurnal variation: associations with medications prescribed to control children's problem behavior. Child Dev 2007;78(3):927-37.

[100] Adriani W, Leo D, Guarino $M$, et al. Short-term effects of adolescent methylphenidate exposure on brain striatal gene expression and sexual/ endocrine parameters in male rats. Ann NY Acad Sci 2006;1074(1):52-73.

[101] Kaneyuki T, Kohsaka M, Shohmori T. Sex hormones metabolism in the brain: influence of central acting drugs on 5 alpha-reduction in rat diencephalon. Endocrinol Jpn 1979;26(3):345-51.

[102] Tsai SC, Chiao YC, Lu CC, et al. Inhibition by amphetamine of testosterone secretion through a mechanism involving an increase of cyclic AMP production in rat testes. Br J Pharmacol 1996;118(4):984-8.

[103] Chatterjee-Chakrabarty S, Miller BT, Collins TJ, Nagamani M. Adverse effects of methylphenidate on the reproductive axis of adolescent female rats. Fertil Steril 2005:84(Suppl 2):1131-8.

[104] Van den Berghe G, de Zegher F, Lauwers P, Veldhuis JD. Luteinizing hormone secretion and hypoandrogenaemia in critically ill men: effect of dopamine. Clin Endocrinol (Oxf) 1994;41(5):563-9.

[105] Nicoletti I, Ambrosi F, Giammartino C, Fedeli L, Mannarelli C, Filipponi P. Catecholamines and pituitary-function. V. Effect of low-dose dopamine infusion on basal and gonadotropin-releasing hormone stimulated gonadotropin release in normal cycling women and patients with hyperprolactinemic amenorrhea. Horm Metab Res 1986;18(7):479-84.

[106] Barnes RB, Cha KY, Lee DG, Lobo RA. Modulation of luteinizing hormone immunoreactivity and bioactivity by dopamine but not norepinephrine in women. Am J Obstet Gynecol 1986;154(2):445-50.

[107] Foresta C, Scanelli G, Marra S, Scandellari C. The influence of gonadal steroids on the dopamine inhibitory effect on gonadotropin release in men. Fertil Steril 1984;42(6):942-5 
ARTICLE IN PRESS

8

B.L. Negrao, M. Viljoen/Medical Hypotheses xxx (2011) xxx-xxx

[108] Ferrari C, Rampini P, Malinverni A, et al. Inhibition of luteinizing hormone release by dopamine infusion in healthy women and in various pathophysiological conditions. Acta Endocrinol (Copenh) 1981;97(4): 436-40.

[109] Quigley ME, Rakoff JS, Yen SS. Increased luteinizing hormone sensitivity to dopamine inhibition in polycystic ovary syndrome. J Chin Endocrinol Meta 1981;52(2):231-4.

[110] Judd SJ, Rigi LA, Yen SS. The effects of ovariectomy and estrogen treatment on the dopamine inhibition of gonadotropin and prolactin release. J Chin Endocrinol Metab 1979;49(2):182-4.

[111] Silverthorn DU [Metabolism and energy balance]. In: Silverthorn DU, editor. Human physiology: an integrated approach. San Francisco: Benjamin Cummings; 2004. p. 696-720.

[112] Martini FH, Neath JL [The endocrine system]. In: Martini FH, Neath JL, editors. Fundamentals of anatomy and physiology. San Francisco: Benjamin Cummings; 2009. p. 604-44.

[113] Guyton AC, Hall JE [Insulin, glucagon and diabetes mellitus]. In: Guyton AC, Hall JE, editors. Textbook of medical physiology. Philadelphia: Elsevier Saunders; 2006. p. 961-77.

[114] Bello NT, Hajnal A. Acute methylphenidate treatments reduce sucrose intake in restricted-fed bingeing rats. Brain Res Bull 2006;70(4-6):422-9.

[115] McMahon EM, Andersen DK, Feldman JM, Schanberg SM. Methamphetamineinduced insulin release. Science 1971;174(4):66-8.

[116] Manzanares J, Cantón R, Grander C, Benedi J, Zaragozá F. Amphetamine and chlorpromazine modify cerebral insulin levels in rats. Life Sci 1988;42(1): 21-5.
[117] Kun DY, Chen JT. Role of cerebral dopamine but not plasma insulin, leptin and glucocorticoid in the development of tolerance to the anorectic effect of amphetamine. Neurosci Res 2002;44(1):63-9.

[118] van Weenen JE, Parlevliet ET, Maechler P, et al. The dopamine receptor D2 agonist bromocriptine inhibits glucose-stimulated insulin secretion by direct activation of the $\alpha 2$-adrenergic receptors in beta cells. Biochem Pharmacol 2010;79(12):1827-36.

[119] Jones PM, Asare-Anane H, Weerasinghe C, Persaud SJ. Dopamine is an introislet regulator of insulin secretion. Diabetes 2007;56(Suppl. 1):A439.

[120] Shankar E, Santhosh KT, Paulose CS. Dopaminergic regulation of glucoseinduced insulin secretion through dopamine D2 receptors in the pancreatic islets in vito. IUBMB Life 2006;58(3):157-63.

[121] Rubik B, Ljubicic S, Pournourmohammadi S, et al. Dopamine D2-like receptors are expressed in pancreatic beta cells and mediate inhibition of insulin secretion. J Biol Chem 2005;280(44):36824-32.

[122] Walters JM, Ward GM, Barton J, et al. The effect of norepinephrine on insulin secretion and glucose effectiveness in non-insulin-dependent diabetes. Metabolism 1997;46(12):1448-53.

[123] Porte Jr D, Williams RH. Inhibition of insulin release by norepinephrine in man. Science 1966;152(3726):1248-50.

[124] Chen H, Straub SG, Sharp GWG. Protein acylation in the inhibition of insulin secretion by norepinephrine, somatostatin, galanin, and PGE[sub 2]. Am J Physiol Endocrinol Metab 2003;48(2):E287-94.

Please cite this article in press as: Negro BL, Viljoen M. Stimulants and growth in children with attention-deficit/hyperactivity disorder. Med Hypotheses

(2011), doi:10.1016/j.mehy.2011.03.015 